\title{
Trade Liberalisation and FDI Inflows in Emerging Economies
}

\author{
Mumtaz Hussain Shah ${ }^{1}$, Yahya Khan ${ }^{2}$
}

\begin{abstract}
This research work evaluates the proposition that trade liberalisation is instrumental in pulling FDI inflows to emerging economies. Using panel random effects model on annual data of 6 emerging countries including Brazil, China, India, Mexico, Russian Federation and Turkey from 1996 to 2014, it is found that liberalisation of trade and investment regime measured by trade agreements significantly affect the multinationals' overseas investment decision. Market size, development level and human capital, considered essential by foreign investors, also have a significant positive effect on incoming FDI. Preferential and regional trade agreements increase the openness of a country's economic and investment borders. They reduce duties, taxes, tariffs as well as the inflexibility in regime policies vis-à-vis foreign firm operations. This usually ensue trade and investment liberalisation and consequentially has a positive impact on FDI inflows to these nations. Among trade agreements only the preferential trade agreement is found to be significantly positive. It is plausible given the fact that except for Mexico all other countries selected are far away from the major FDI source nations.
\end{abstract}

Keywords: Emerging six countries, foreign direct investment, panel data and trade liberalisation.

\section{Introduction}

According to fifth edition of the IMF's Balance of Payments Manual (BPM5), Foreign Direct Investment, normally known as FDI, refers to an investment made to obtain permanent or long-term interest in ventures functioning outside the borders of the country of the investor (IMF, 1993). FDIs give an opportunity to investors to invest in markets around the globe with lesser risk and maximum possible benefits (Dennis \& Christopher, 2005). The nature of FDI is different from other types of transnational investments as it is generally encouraged by long-term perspectives mostly in manufacturing activities (Tsen, 2005). Economic growth and greater financial development are usually linked with higher FDI inflows due to associated transfer of technology and superior management practices (Carkovic \& Levine, 2005). It contributes more towards sustained economic development as compared to

1 Assistant Professor, IMS, University of Peshawar, corresponding author email address: shah_mumtaz@ hotmail.com

2 Postgraduate Scholar, IMS, University of Peshawar 
local investments (Borensztein, De Gregorio, \& Lee, 1998 and Shah, 2009). During 1990 's, FDI inflows to developing countries increased manifold because of intensive trade liberalisation (Brooks, Fan, \& Sumulong, 2003 and Shah, 2011a). During the worldwide financial crisis of 2009, emerging markets drew more FDI compared to developed economies probably due to rapid growth of China and India and lesser cost of investment (Kekic, 2011; Shah, 2015).

Variables like market size, development level, economic openness, human capital and trade liberalisation generally positively affect FDI inflows to a country (Shah \& Afridi, 2015). Nations signing preferential trade agreements (PTAs) with bigger trade partners encourage domestic-export platform and promote FDI inflows (Blanchard, 2007). Similarly, domestic market size plays an active part in pulling FDIs to developing countries in the long run (Shah, 2011f). Human capital has significant positive relation with incoming FDIs and its importance has increased over time (Noorbakhsh, Paloni, \& Youssef, 2001). Likewise, GDP per capita, indicating average standard of living, significantly affects the flow of FDIs in middle and lower income economies (Yasmin, Hussain, \& Chaudhary, 2003).

The main goal of this research study is to evaluate the impact of trade liberalisation on inward FDIs in emerging six countries, namely Brazil, China, India, Mexico, Russian Federation and Turkey. Using annual data for the time period of 19 years i.e. 1996 to 2014 and applying random effects model, it is found that decreasing corporate tax rate and tariffs on foreign goods and services play a significant role in attracting FDIs to a state (Arbatili, 2011). Furthermore, the results revealed that PTAs have significant positive relationship with cross boarder investments. This shows that trade liberalisation is one of the important factors for the growth of FDI inflows in emerging countries (Shah, 2010). The empirical results of the study also suggest that market size, development level of the country, and the availability of skilled and educated labour are essential factors which cause an increase in inward FDIs to emerging countries. This study has two-fold objectives. First objectives is to analyse the effect of trade liberalisation on foreign direct investment. And the second objective is to elaborate the importance of decreasing trade barriers through trade agreements, i.e. preferential and regional trade agreements for inward foreign direct investment.

Rest of the paper is organized as follows: Section 2 gives an account of literature review synthesising previous knowledge regarding the topic. Section 3 contains information about research type, sample size, methodology and explanation regarding variables of the study. Data analysis and results are discussed in Section 4. Section 5 concludes the paper.

\section{Literature Review}


This section is divided in two parts. The first one discusses the conventional FDI determinants and the second part concentrates on trade liberalisation.

\subsection{Traditional Foreign Direct Investment (FDI) Determinants}

Holland and Pain (1998) studied eight European Union transition economies and found that FDI was attracted by factors such as privatization, openness of the host economy to foreign investor, trade agreements, labour cost and inflation of the host location. Checchi, Simone, and Faini (2007) analysed the relationship between skilled migration and FDI and concluded that overseas investment have a negative relationship with secondary school enrolment but a positive relation was observed between FDI and tertiary enrolments. They also pointed out that the migration of skilled workers (tertiary educated) cause reduction in local human capital and negatively affect FDI inflows. Majeed and Ahmad (2008) examined human resource development and FDI in developing countries and concluded that health expenditures have positive impact on overseas investment, whereas government spending, military consumption and wages have a negative influence on FDI. Akin (2009) probed market size as possible determinant of cross boarder investments in developing countries from 1980 to 2000. By applying cross sectional OLS, he showed that GDP per capita is a weak proxy for market seeking FDIs in developing economies but otherwise population and GDP are important indicators. The study also reflected that higher life expectancy and young population will cause more FDI inflows as compared to aging work force.

Azman-Saini, Law, and Ahmad (2010) evaluated FDI, economic improvement and the role of financial markets. Using data of 91 countries from 1975 to 2005, through threshold regression, they found that FDI affect economic growth positively only if the financial market development crosses a threshold. Therefore, government role is important apropos policies promoting financial market expansion because it positively influences FDI inflows. Goh (2011) studied the impact of government policies and size of host market on Malaysian outgoing FDI. They concluded that there is a positive relationship between Malaysian outgoing FDI, market size, exchange rate stability and trade openness. Tiwari and Mutascu (2011) worked on FDI and economic expansion in 23 Asian countries. They found that both cross boarder investments and exports improved the growth mechanism. Moreover they stressed that capital and labour also play a vital role in economic expansion.

Kolstad and Wiig (2012) worked on the determinants of China's outward FDI and concluded that it is driven by large markets and abundant natural resources. Sharifi-Renani and Mirfatah (2012) explored the determinants of FDI in Iran from 1980 to 2006 and showed that GDP, openness, and stable exchange rate positively affect inward FDI in Iran, whereas exchange rate and crude oil price volatility deter 
overseas investments (Shah, 2013b). These research studies clearly manifest the importance of market size, development level, openness and human capital among the established typical locational FDI determinants (Shah, 2012a). They are discussed in detail in section three.

\subsection{Trade Liberalisation and Foreign Direct Investment}

Frankel, Stein, and Wei (1996) worked on regional trade agreements (RTAs) and investigated trade amongst 63 countries from 1965 to 1992 using gravity model ${ }^{3}$. They argued that attractiveness of RTAs depends upon regionalization enhanced to the optimal level and the extent of transportation costs between countries. They concluded that if carriage cost is high between regions, trade volume will be low; and if conveyance cost is low, higher trade activity shall be observed. Similarly, Asiedu (2002) worked on the impact of trade openness on FDI in 71 sub-Saharan African (SSA) and non-SSA emerging countries from 1988 to 1997 and found that openness to trade enhances the growth of FDI in SSA and also in non-SSA countries but the ratio of benefit from trade openness is more for non-SSA countries as compared to SSA nations. Binh and Jonathan (2002) assessed trade openness and FDI inflows in 16 Asian economies from 1990 to 1999 . They asserted that bilateral trade agreements (BTAs) caused 30\% more FDI form United States in first year and it doubled in the following years. This caused additional economic growth of $0.6 \%$ annually. The study also suggested that this growth is subject to the host joining World Trade Organization (WTO).

Addison and Heshmati (2003) investigated the relationship between FDI and trade openness in 110 developed and emerging countries for the period of 1970 to 1999 and found that trade openness has significant impact on FDI but this impact was comparatively small and varied by region. Jaumotte (2004) investigated whether market size of RTA member countries had any impact on FDI and concluded that there is a positive significant relationship between RTA countries' market size and overseas investment. He also asserted that not all members in the RTA had the same advantages from such an agreement because countries having adept educated labour and financial stability attracted more FDIs as compared to other RTA participants (Shah, 2012c). Aizenman and Ilan (2006) did a research work on trade and FDI and the linkage between them. They analysed 81 countries' data from 1982 to 1998 and asserted that there was a strong linkage between trade and FDI in developing countries as compared to industrialized countries due to lower trade barriers. Goldar and Banga (2007) evaluated the impact of FDI and trade openness in 78 Indian firms.

3. Gravity model postulates that trade and investment among two countries is directly proportional to the product of their gross national product and inversely proportional to the distance between them (Shah, 2011e and Shah, 2013a). 
They identified that trade liberalisation positively affects cross-border investment inflows in India. Greenaway, Sapsford, and Pfaffenzeller (2007) studied the effects of trade liberalisation and openness on FDI in 54 emerging economies from Latin America, Africa and Asia for 1990 to 2000 and found that trade openness has a positive significant impact on FDI. However, this impact was smaller for middle income economies as compared to low income ones.

Büthe and Milner (2008) assessed the impact of politics and international trade agreements on inward FDI in developing countries. They found that lesser government intervention in the economy, and liberal trade policies through preferential and multilateral trade agreements increase inward FDI. Martens (2008) conducted an empirical work on the relationship between FDI and trade liberalisation in emerging economies. He analysed 21 selected research studies published during 1999 to 2007 by using computable general equilibrium model. In this study the author showed that trade and FDI have complementary relationship rather than being substitutes to one another. This survey also identified that most of the cross-border investments going to emerging regions were vertical in nature ${ }^{4}$. Páez (2008) analysed the data of G-3 countries: Colombo, Mexico, Venezuela, and Andean Community of Nations (ACN) from 1992 to 2001 by using gravity model. The author concluded that increased membership of free trade agreements (FTAs) is favourable for trade as compared to FDI. This study showed that RTAs reduced the barriers for trade and diverted FDI in ACN due to lake of investment protection. Chandran (2009) investigated the association between trade liberalisation and manufacturing expansion in Malaysia. Using data from 1970 to 2003, it is concluded that there is a positive relationship between trade openness and growth in manufacturing sector. The author also suggested that openness increased their scale of production which helped them to achieve growth.

Im (2012), using cross border sales of US multinational subsidiaries in 1982, 1989, 1994, and 1999, examined the effect of market size and trading alliances on U.S' outgoing FDI and found that constructing trading blocs drew more FDI as compared to non-member regions. He also found that the market size of a larger bloc positively influences FDI in comparison to a smaller trade bloc. Kim, Kim, and Kim (2012) analysed the effects of PTAs on smaller economies. They worked on inward FDI of 15 economies who signed FTAs with United States of America from 1982 to 2010. They asserted that small economies are inclined to sign a PTA or join existing RTAs of large economies in the hope of higher FDI inflows. Medvedev (2012) investigated the impact of preferential and other trade agreements on FDI inflows. He analysed 87 countries from 1980 to 2004 through panel analysis and asserted that there is a

4. The type of FDI in which the parent company, or one of its subsidiary supply semi-finished products as raw material for value addition in another subsidiary or to the parent firm (Shah, 2011a). 
significant positive relationship among PTAs and inward FDI. He also found that both PTA membership and size of the market were important factors for PTAs and FDI association. He also revealed that this significant relationship is only between lower and middle income regions and supported that increased FDI inflows in developing countries in 1990's and 2000's is due to "deep integration", a time span in which majority of PTAs have been signed (Shah, 2011b). Kim, Lin, and Suen (2013) worked on trade liberalisation and FDI and their impact on domestic investment. They used cross-sectional data of 85 countries and stressed that trade has negative impact on local investments in regions having inferior human capital, a meagre financial maturity or extreme corruption and vice versa. On the contrary, FDI have positive impact on local investments in countries with less human capital, little financial development or intense corruption.

Foreign direct investment, trade and investment liberalisation literature reveals mixed results. In some cases, FTAs are causing FDI whereas in others it's the PTAs. Yet in other instances RTAs are instrumental in luring overseas investors. Moreover, there are occasions where researchers did not distinguish between the different types of trade agreements and used them collectively (Shah, 2011d). Hence the effect of trade liberalisation on FDI is conditional not only on the type of trade agreements but also on the set of years and countries chosen as sample. Therefore, this phenomenon is an open empirical question which needs academics' attention to further our understanding of the subject, especially for the countries, regions and time periods that are not analysed so far.

\subsection{Research Hypotheses}

The following hypothesis are developed in light of the literature review to answer the research question of the study

$\mathrm{H}_{0}$ : There is no significant impact of trade liberalisation on FDI inflows in an emerging economy.

$\mathrm{H}_{1}$ : There is a significant positive impact of trade liberalisation on FDI inflows in an emerging economy.

\section{Methodology}

In order to investigate the impact of trade liberalization on FDI inflows in six emerging economies, panel random effects method is used. Total population, GDP per capita, total trade, primary education, preferential trade agreements and regional trade agreements are used as proxies for market size, development level, openness, human capital, and trade liberalization, respectively based on the findings of the 
literature review. The empirical estimation model is as follow:

$$
F D I_{j t}=f\left\{\begin{array}{c}
\text { Market Size }_{j t}+\text { Development Level }_{j t}+\text { Openness }_{j t}+ \\
\text { Human Capital }_{j t}+\text { Trade Liberalization }_{j t}+\varepsilon_{j t}
\end{array}\right\}
$$

After putting appropriate proxies for each independent variable and applying the natural logarithm for linearizing the data, equation 1 is modified to equation 2 as under:

$$
L n F D I_{j t}=\begin{gathered}
\alpha_{0}+\beta_{1} L n P O P_{j t}+\beta_{2} L n G D P P C_{j t}+\beta_{3} L n T_{r a d e}+ \\
\beta_{4} L n P R I_{j t}+\beta_{5} L n R T A s_{j t}+\beta_{6} L n P T A s_{j t}+\varepsilon_{j t}
\end{gathered}
$$

Where,

$\alpha$ is constant,

Ln is used for natural logarithm. It usually reduces heteroscedasticity in the variables (Shah, 2012b),

$J$ represents countries from 1 to 6 , whereas the subscript t represents time from 1 to 19 years, i.e.1996 to 2014 ,

$\varepsilon$ is the error term.

The proxies, abbreviations and the data sources for all the variables are given in Table 1 .

The dependent and all the explanatory variables are briefly explained below.

Table 1: Variable Description, Symbols, Data Sources

\begin{tabular}{|c|c|c|c|}
\hline Variables & Proxy Used & Abbreviations & Data Source \\
\hline Foreign Direct Investment & FDI Stock & Ln FDI & UNCTAD \\
\hline Market Size & Total Population & Ln POP & WORLD BANK \\
\hline Development Level & GDP per Capita & Ln GDPPC & WORLD BANK \\
\hline Human Capital & Primary Education & Ln PRI & BARRO and LEE \\
\hline Openness & $\begin{array}{c}\text { Trade as a percentage } \\
\text { of GDP }\end{array}$ & Ln Trade & WORLD BANK \\
\hline Trade Liberalisation & $\begin{array}{c}\text { Regional Trade } \\
\text { Agreements }\end{array}$ & Ln RTAs & WTO \\
\cline { 2 - 4 } & $\begin{array}{c}\text { Preferential Trade } \\
\text { Agreements }\end{array}$ & Ln PTAs & WTO \\
\hline
\end{tabular}




\subsection{Foreign Direct Investment}

According to World Bank, FDI is the net incoming investment to obtain a long-lasting management interest, i.e. acquiring a minimum of $10 \%$, in a company working in a country other than that of the investor (Shah \& Qayyum, 2015). This study is mainly about determining the impact of trade liberalisation on FDI inflows in emerging six countries. Therefore, FDI inflow is taken as dependent variable. Moreover, the study has also controlled for the effect of conventional locational FDI pull factors.

\subsection{Market Size}

Market size is defined as the number of possible buyers and sellers in a particular market and is measured in terms of total population. Greater market size is expected to provide additional possibilities of selling the product (Shah, 2012d). Therefore, a positive rapport with FDI is assumed.

\subsection{Economic Development Level}

Development level is the extent to which the nation is economically developed. It also shows the standard of living of the residents of a particular country. GDP per capita is used as a proxy for this variable. As development proceeds the ability of the people to buy value added multinational products also increases (Shah, 2014b). Positive relationship is assumed between development level and incoming FDI.

\subsection{Openness}

An open economy is classified as a market where all people and firms have equal prospects of availing the existing opportunities to prosper and grow. It also covers the possibilities of entry and exit from the host market. Trade, i.e. imports and exports, as a percentage of GDP is used as a proxy for it. Openness also means lesser restrictions on import of raw materials and export of finished goods (Shah \& Samdani, 2015). A positive impact is expected on FDI inflows.

\subsection{Human Capital}

Human capital is defined as the characteristic of a person to be productive. Being healthy, educated, capable, skilled and knowledgeable will make him rich in human capital (Shah, 2014a). Primary education attainment level in a country is used as a proxy for this variable. The relationship between human capital and incoming FDI is assumed to be positive. 


\subsection{Trade Liberalisation}

Encouraging free exchange of investments, goods and services by removing barriers like high duties, hefty taxes, surcharges and complex procedures amid countries lead to trade and investment liberalisation. Trade liberalisation is the main variable of interest of this study. Two proxies, i.e. Preferential Trade Agreements and Regional Trade Agreements are used for it in the current study.

\subsubsection{Preferential Trade Agreements}

According to WTO, these are one-sided trade agreements based on a preferential trade treaty among countries that decrease tariffs for certain goods of the country with which they have undergone these types of agreements. The tariffs are not necessarily abolished but lessened in comparison to other nations not part of the agreement.

\subsubsection{Regional Trade Agreements}

WTO defines regional trade agreements as reciprocal trade agreements between two or more neighbouring nations who mainly coordinate with each other in all trade related activities. Regional trade agreements prefer free trade amongst nations of specified region who are part of the agreement, e.g. a free trade area like North American Free Trade Agreement (NAFTA) and custom unions such as European Union (EU).

Increase in PTAs and RTAs are expected to attract more FDI to a country or region due to the associated investment and trade liberalisation (Shah, 2011c). Therefore, the study also assumes a positive effect of PTAs and RTAs on inward FDI.

\subsection{Empirical Estimation Issues}

Certain estimation issues related to empirical research need to be considered before we start estimating and discussing the results. They include the following:

\subsubsection{Summary Statistics}

Summary statistics for all the variables used in the empirical estimations are given in Table 2.

Values are rounded off to four decimal places

\subsubsection{Heteroscedasticity}


Table 2: Summary Statistics

\begin{tabular}{|c|c|c|c|c|c|c|c|}
\hline Variable Name & Proxy & Obs. & Min & Max & Mean & Median & Variance \\
\hline $\begin{array}{c}\text { Foreign Direct } \\
\text { Investment }\end{array}$ & Ln FDI & 114 & 19.0085 & 27.2488 & 24.8523 & 25.158 & 2.2959 \\
\hline Market size & Ln POP & 114 & 17.8376 & 21.0142 & 19.3243 & 18.8369 & 1.3056 \\
\hline $\begin{array}{c}\text { Development } \\
\text { Level }\end{array}$ & Ln GDPPC & 114 & 5.7351 & 9.3675 & 7.8529 & 8.0432 & 1.0106 \\
\hline Openness & Ln Trade & 114 & 2.7684 & 4.7147 & 3.7280 & 3.8737 & 0.1673 \\
\hline Human Capital & Ln PRI & 114 & 1.3558 & 4.3742 & 2.6965 & 2.7538 & 0.8174 \\
\hline $\begin{array}{c}\text { Trade Liberalisa- } \\
\text { tion }\end{array}$ & Ln RTA's & 114 & 0.0000 & 2.1972 & 0.3233 & 0.0000 & 0.2251 \\
\cline { 2 - 8 } & Ln PTA's & 114 & 0.0000 & 1.3863 & 0.0948 & 0.0000 & 0.0867 \\
\hline
\end{tabular}

The standard errors are biased when heteroscedasticity is present. This in turn leads to bias in test statistics and confidence intervals. Therefore, to check for the presence of heteroscedasticity, Breush-Pagan / Cook-Weisberg Test for heteroscedasticity was performed. Table 3 shows the existence of heteroscedasticity in the data. The problem was resolved by using robust standard errors.

\subsubsection{Multicollinearity}

Table 3: Breusch - Pagan / Cook - Weisberg Test Results

\begin{tabular}{|c|c|c|c|}
\hline Variable(s) & Chi $^{2}$ & Probability $>\mathrm{Chi}^{2}$ & Decision \\
\hline Ln FDI & 28.42 & 0.0000 & Heteroscedastic \\
\hline Ln GDP & & & \\
Ln Population & & & \\
Ln GDPPC & & & \\
Ln Trade & & 0.0000 & \\
Ln Pri Edu \\
Ln RTA's \\
Ln PTA's
\end{tabular}

To gauge the extent of multicollinearity between the independent variables, variance inflation factor were calculated for all the explanatory variables. Table 4 shows the VIF results.

Since the VIF value for all explanatory variables is less than 5 , this shows that the problem of multicollinearity does not exist (Shah \& Faiz, 2015).

3.7.4 Hausman Specification Test 
Table 4: VIF for Multicollinearity

\begin{tabular}{|c|c|c|}
\hline Variables & VIF & $1 /$ VIF \\
\hline Ln GDPPC & 2.94 & 0.3401 \\
\hline Ln Population & 2.63 & 0.3808 \\
\hline Ln Primary Education & 1.64 & 0.6109 \\
\hline Ln Trade & 1.39 & 0.7192 \\
\hline Ln RTA's & 1.28 & 0.7787 \\
\hline Ln PTA's & 1.13 & 0.8845 \\
\hline Mean VIF & \multicolumn{2}{|c|}{1.83} \\
\hline
\end{tabular}

In order to test for suitable panel estimation method, we carried out the Hausman (1978) specification test. The test results are given in Table 5.

Since the p-value for Hausman test is greater than the conventional level of sig-

Table 5: Hausman Specification Test

\begin{tabular}{|c|c|c|c|}
\hline \multirow{2}{*}{ Variables } & \multicolumn{2}{|c|}{ Coefficients } & \multirow{2}{*}{$(\mathrm{b}-\mathrm{B})$} \\
\cline { 2 - 3 } & (b) & (B) & \\
\cline { 2 - 3 } & $\mathrm{fe}$ & re & Difference \\
\hline Ln GDPPC & 6.2626 & 1.400 & 4.8617 \\
\hline Ln Population & 1.4778 & 1.6714 & -0.1936 \\
\hline Ln Primary Education & -0.1095 & 0.4471 & -0.5566 \\
\hline Ln Trade & 0.4829 & 0.3426 & 0.1403 \\
\hline Ln RTA's & -0.7385 & -0.7116 & -0.0268 \\
\hline Ln PTA's & 0.0179 & 0.1219 & -0.1041 \\
\hline
\end{tabular}

$\mathrm{b}=$ consistent under Ho and $\mathrm{Ha}$; obtained from xtreg

$\mathrm{B}=$ inconsistent under $\mathrm{Ha}$, efficient under Ho; obtained from xtreg

Test: Ho: difference in coefficients not systematic

Chi2 (6) $=\left(\right.$ b-B) $'\left[\left(V_{-} \text {b-V_B }\right)_{-} \wedge(-1)\right](b-B)=1.16$

Probability $>$ Chi2 $=0.9789$

(V_b-V_B is not positive definite)

nificance, we are therefore unable to reject the null hypothesis that random effects model will yield better results than fixed effects model. Therefore, in regression analysis, random effects panel estimation technique is applied.

\section{Results \& Analysis}


Table 6 shows the regression results of the study. Column 1 shows a significant positive coefficient for the market size, indicating that an increase in the host market size will have a positive impact on FDI inflows. The addition of development level in Column 2 demonstrates with its high positive significance that increase in the development level of the country will attract more FDI. Column 3 includes trade openness, which proves to be insignificant. Market size and development level remains significant with a positive coefficient. This validates the importance of economic progress and multinationals' ability to sell products in the host country for overseas investors. The same is true regarding human capital as evident from the regression

Table 6: Regression Results

\begin{tabular}{|c|c|c|c|c|c|c|c|}
\hline Variable & $\begin{array}{l}\text { Proxy } \\
\text { Used }\end{array}$ & 1 & 2 & 3 & 4 & 5 & 6 \\
\hline $\begin{array}{c}\text { Market } \\
\text { Size }\end{array}$ & Ln POP & $\begin{array}{c}0.6593 \\
* * *(0.1986)\end{array}$ & $\begin{array}{c}1.2713 * * * \\
(0.1389)\end{array}$ & $\begin{array}{c}1.2731 \text { *** } \\
(0.1665)\end{array}$ & $\begin{array}{c}1.4397^{* * *} \\
(0.1392)\end{array}$ & $\begin{array}{c}1.4102 * * * \\
(0.1281)\end{array}$ & $\begin{array}{c}1.4130 * * * \\
(0.1277)\end{array}$ \\
\hline $\begin{array}{c}\text { Devel- } \\
\text { opment } \\
\text { Level }\end{array}$ & $\begin{array}{c}\text { LnGDP- } \\
\text { PC }\end{array}$ & & $\begin{array}{c}1.6696^{* * *} \\
(0.3116)\end{array}$ & $\begin{array}{c}1.6672 * * * \\
(0.3493)\end{array}$ & $\begin{array}{c}1.6856^{* * *} \\
(0.2133)\end{array}$ & $\begin{array}{c}1.6878^{* * *} \\
(0.1805)\end{array}$ & $\begin{array}{c}1.6416 \text { *** } \\
(0.2121)\end{array}$ \\
\hline Openness & $\begin{array}{c}\text { Ln } \\
\text { Trade }\end{array}$ & & & $\begin{array}{c}-0.1014 \\
(0.8974) \\
\end{array}$ & $\begin{array}{c}0.2389 \\
(0.4396)\end{array}$ & $\begin{array}{l}0.4493 \\
(0.3175) \\
\end{array}$ & $\begin{array}{c}0.2451 \\
(0.4379) \\
\end{array}$ \\
\hline $\begin{array}{l}\text { Human } \\
\text { Capital }\end{array}$ & Ln PRI & & & & $\begin{array}{c}0.4552 * * \\
(0.2003)\end{array}$ & $\begin{array}{l}0.3370 \text { * } \\
(0.1831)\end{array}$ & $\begin{array}{c}0.4634 \text { ** } \\
(0.2084)\end{array}$ \\
\hline \multirow{2}{*}{$\begin{array}{l}\text { Trade } \\
\text { Liberalisa- } \\
\text { tion }\end{array}$} & $\begin{array}{c}\text { Ln } \\
\text { RTA's }\end{array}$ & & & & & $\begin{array}{c}-0.7272 \\
(0.5942)\end{array}$ & \\
\hline & $\begin{array}{l}\text { Ln } \\
\text { PTA's }\end{array}$ & & & & & & $\begin{array}{l}0.3295^{*} \\
(0.1967)\end{array}$ \\
\hline \multicolumn{2}{|c|}{ No. Of Observations } & 114 & 114 & 114 & 114 & 114 & 114 \\
\hline \multicolumn{2}{|c|}{ R-Squared } & $45.80 \%$ & $59.69 \%$ & $59.80 \%$ & $64.80 \%$ & $68.99 \%$ & $65.18 \%$ \\
\hline
\end{tabular}

Values are rounded up to four decimal places. The coefficients for all the variables are quoted with their standard errors reported in parenthesis. All the standard errors are robust to heteroscedasticity. ${ }^{*}$ indicates significance at $10 \%,{ }^{* *}$ at $5 \%$ and ${ }^{* * *}$ at $1 \%$ significance level.

results in Column 4 which manifests that an increase in the human capital exerts a positive influence on incoming FDI.

Adding regional trade agreement as a proxy for trade liberalisation in Column 5 proves that RTAs have insignificant relationship with FDI. Including preferential trade agreement as a proxy of trade liberalisation, the regression results in Column 6 indicates that the coefficient of PTA is positively significant. This indicates that an increase in the number of PTAs signed by a host country with other nations will have 
a positive effect on FDI inflows. The value of R-squared for the last model is 0.6518 . This means that the overall effect of all the independent variables on the dependent variable is $65.18 \%$ or these variables can collectively explain about 65 percent of the variation in FDI inflows in the emerging six economies.

If we recall the emerging economies included in the sample, i.e. Brazil, China, India, Mexico, Russian Federation, and Turkey, it can be seen from the list that except for Mexico none other country is an immediate neighbour of any major FDI source nation. This may probably be the reason that the coefficient for regional trade agreements is insignificant and that for preferential trade agreements is positively significant. Moreover, the presence of major FDI recipients, i.e. China, India and Brazil being distant hosts from the source FDI nations can only benefit from a preferential or free trade agreement.

\section{Conclusion}

This study confirms that there is a positive association between trade liberalisation and foreign direct investments. This implies that if a country implements trade and investment liberalisation, its attractiveness for potential overseas investors' increases. The reduction in economic border costs, i.e. tariffs and duties on foreign goods and services, flexible government policies and low transaction costs encourage other countries to sign preferential trade agreements with emerging six economies which affects the multinationals' location choice and positively contributes toward increasing inward FDI.

The results also reveal that the relationship between market size and FDI is positive. Expansion in market size, i.e. increase in the number of buyers will cause an increase in incoming FDI in emerging six countries. Development level and human capital accretion have positive sway on the FDI inflows. Growth in the ability of people to buy foreign goods and services augments FDI inflows. Similarly, a country with educated and skilled labour will also draw more foreign direct investment.

However, it shall be kept in mind that the current findings are based on the data collected from 1996 to 2014 for the six emerging countries, i.e. Brazil, China, India, Mexico, Russian Federation, and Turkey. Therefore, the academics and policy makers, though will benefit from this research, shall be careful about any generalisation. Moreover, it is suggested that the availability of disaggregated sectoral data can help future researchers to add further micro level insights to the subject.

\section{References}

Addison, T. A., \& Heshmati, A. (2003). The new global determinants of FDI flow to developing coun- 
tries. World Institute for Development Economics Research, DP No.2003/45, 1-31.

Aizenman, J., \& Ilan, N. (2006). FDI and trade two-way linkages? The Quarterly Review of Economics and Finance, 46(3), 317-337.

Akin, M.S. (2009). How is the market size relevant as a determinant of FDI in developing countries? A research on population and the cohort size. International Symposium on Sustainable Development, June 9-10 2009, Sarajevo, 425-429.

Arbatili, E. (2011). Economic Policies and FDI Inflows to Emerging Markets Economics. International Monetary Fund, WP/11/192, 1-26.

Asiedu, E. (2002). On the determinants of foreign direct investment to developing countries: Is Africa different? World Development, 30(1), 107-119.

Azman-Saini, W. N. W., Law, S. H., \& Ahmad, A. H. (2010). FDI and economic growth: New evidence on the role of financial markets. Economics Letters, 107(2), 211-213.

Binh, N. N., \& Jonathan, H. (2002). Trade liberalisation and foreign direct investment in Vietnam. ASEAN Economic Bulletin, 19. 302-318.

Blanchard, E. J. (2007). Foreign direct investment, endogenous tariffs, and preferential trade agreements. The BE Journal of Economic Analysis EO Policy, 7(1), 1-52.

Borensztein, E., De Gregorio, J., \& Lee, J. W. (1998). How does foreign direct investment affect economic growth? Journal of International Economics, 45(1), 115-135.

Brooks, D. H., Fan, E. X., \& Sumulong, L. R. (2003). Foreign direct investment in developing Asia: trends, effects, and likely issues for the forthcoming WTO negotiations. Asian Development Bank. ERD/WP/38, 1-44.

Büthe, T., \& Milner, H. V. (2008). The politics of foreign direct investment into developing countries: Increasing FDI through international trade agreements? American Journal of Political Science, 52(4), $741-762$.

Carkovic, M., \& Levine, R. (2005). Does foreign direct investment accelerate economic growth? In Moran, T., Graham, E., \& Blomström, M. (Eds.), Does foreign direct investment promote development? (pp. 195 220). Institute for International Economics and Center for Global Development, Washington, DC.

Chandran, V. G. R. (2009). Trade openness and manufacturing growth in Malaysia. Journal of Policy Modeling, 31(5), 637-647.

Checchi, D., De Simone, G., \& Faini, R. (2007). Skilled migration, FDI and human capital investment. IZA Discussion Paper No. 2795, 1-32.

Dennis, B., \& Christopher, L. (2005). A portfolio diversification motive for FDI: Theory and evidence. University of Pacific, 3601 Pacific Avenue. CA/2005/papers/0607, 1-63.

Frankel, J. A., Stein, E., \& Wei, S. J. (1998). Continental trading blocs: Are they natural or supernatural? 
In The Regionalization of the World Economy (pp. 91-120). University of Chicago Press.

Goh, S. K. (2011). Malaysia's outward FDI: The effects of market size and government policy. Journal of Policy Modeling, 33(3), 497-510.

Goldar, B., \& Banga, R. (2007). Impact of trade liberalization on foreign direct investment in Indian industries. Asia Pacific Research and Training Network on Trade, WP NO.3607, 1-28.

Greenaway, D., Sapsford, D., \& Pfaffenzeller, S. (2007). Foreign direct investment, economic performance and trade liberalisation. The World Economy, 30(2), 197-210.

Hausman, J.A. (1978). Specification tests in econometrics. Econometrica, 46(6). 1251-1271.

Holland, D., \& Pain, N. (1998). The determinants and impact of foreign direct investment in transition economies: Panel data analysis. National Institute of Economics and Social Research, P96-6086-R, 1-24.

IMF, (1993). Balance of Payments Manual 5th Edition, International Monetary Fund. Washington DC.

Im, H. (2012). The effects of trading blocs on US outward FDI activity: The role of extended market size. Journal of East Asian Economic Integration, 16(2), 205-225.

Jaumotte, M. F. (2004). Foreign direct investment and regional trade agreements: The market size effect revisited. International Monetary Fund. WP/04/206, 1-32.

Kekic, L. (2011). The global economic crisis and FDI flows to emerging markets. FDI Perspectives, 2.

Kim, D. H., Lin, S. C., \& Suen, Y. B. (2013). Investment, trade openness and foreign direct investment: Social capability matters. International Review of Economics $\mathcal{E}$ Finance, 26, 56-69.

Kim, S. K., Kim, M., \& Kim, Y. H. (2012). The impacts of PTA formation on small economies' tax competition for FDI inflows. Economic Modelling, 29(6), 2734-2743.

Kolstad, I., \& Wiig, A. (2012). What determines Chinese outward FDI? Journal of World Business, 47(1), 26-34.

Majeed, M.T., \& Ahmad, E. (2008). Human capital development and FDI in developing countries. Journal of Economic Cooperation, 29(3), 79-104.

Martens, A. (2008). Trade liberalization and foreign direct investment (FDI) in emerging countries: An empirical survey. Department of Economics, University of Montreal.

Medvedev, D. (2012). Beyond trade: the impact of preferential trade agreements on FDI inflows. World Development, 40(1), 49-61.

Noorbakhsh, F., Paloni, A., \& Youssef, A. (2001). Human capital and FDI inflows to developing countries: New empirical evidence. World development, 29(9), 1593-1610.

Páez, L. (2008). Regional trade agreements and foreign direct investment: Impact of existing RTAs on FDI and trade flows in the Andean Community and implications of a hemispheric RTA in the 
Americas. Swiss Review of International Economic Relations, 1-32.

Shah, M. H. (2009). FDI induced growth in developing countries: Does human capital matter? PhD Conference. $5^{\text {th }} \& 11^{\text {th }}$ March, 2009. Economics Department, University of Leicester, Leicester, UK.

Shah, M. H. (2010). Bilateral linkages with OECD and FDI inflows in leading developing countries. The Fifth International Conference on Interdisciplinary Social Sciences. 2-5 August, 2010. University of Cambridge, Cambridge, UK.

Shah, M. H. (2011a). Bilateral linkages with OECD and FDI inflows in leading developing countries. International Journal of Interdisciplinary Social Sciences, 5(7), 255-270.

Shah, M. H. (2011b). Essays on foreign direct investment in developing countries. Doctoral dissertation, University of Leicester.

Shah, M. H. (2011c). The effect of associations with OECD economies on FDI inflows in leading/emerging developing countries. $4^{\text {th }}$ Italian Doctoral Workshop in Economics and Policy Analysis. 7-8 July, 2011. University of Torino and Collegio Carlo Alberto, Via Real Collegio 30, 10024 Moncalieri, Torino, Italy.

Shah, M. H. (2011d). Networking with OECD economies, enhancing inward FDI in emerging developing countries. $7^{\text {th }}$ UK Social Networks Conference. 7-9 July, 2011. University of Greenwich, Greenwich Campus, Old Royal Naval College, London, UK.

Shah, M. H. (2011e). World Trade Organisation and inward foreign direct investment in developing countries: is it TRIMS, TRIPS or Liberalisation? $6^{\text {th }}$ International Conference on Interdisciplinary Social Sciences. 11-13 July, 2011. University of New Orleans, 2045 Lakeshore Drive, CERM 245, New Orleans, LA 70122, USA.

Shah, M. H. (2011f). The significance of infrastructure for inward FDI in developing countries. International Conference on Applied Business \& Economics, ICABE, 2011. 29 $9^{\text {th }}$ September to $1^{\text {st }}$ October, 2011. University of Applied Sciences, Metropolitan Hotel, 385 Syngrou Ave, 17564, Athens, Greece.

Shah, M. H. (2012a). The importance of adherence to Intellectual Property Rights (IPRs) treaties / conventions for FDI inflows in emerging economies: evidence from OECD outward FDI. International Network for Economic Research, 14 ${ }^{\text {th }}$ INFER Annual Conference. 10-13 May, 2012. Faculty of Economics, University of Coimbra, Portugal.

Shah, M. H. (2012b). The significance of infrastructure for FDI inflow in developing countries. International Network for Economic Research, 14 $4^{\text {th }}$ INFER Annual Conference. 10-13 May, 2012. Faculty of Economics, University of Coimbra, Portugal.

Shah, M. H. (2012c). The effect of macroeconomic stability on inward FDI in developing countries. $7^{\text {th }}$ International Conference on Interdisciplinary Social Sciences. 25-28 June, 2012.Universidad Abat Oliba CEU, Bellesguard 30-08022, Barcelona, Spain.

Shah, M. H. (2012d). The significance of infrastructure for FDI inflow in developing countries. Challenges for 
Analysis of the Business and the Economy[Scientific Conference. 13-16 September, 2012. University of Applied Sciences, Bahnhofstrasse, 15745 Wildau, Berlin, Germany.

Shah, M. H. (2013a). The importance of adherence to Intellectual Property Rights (IPRs) treaties/ conventions for FDI inflows in emerging economies: evidence from OECD outward FDI. European Economics and Finance Society, EEFS2013, The Twelfth Annual EEFS Conference. 20-23 June, 2013. Westin Grand, Berlin, Germany.

Shah, M. H. (2013b). The effect of macroeconomic stability on inward FDI in developing countries. European Economics and Finance Society, EEFS2013, The Twelfth Annual EEFS Conference. 20-23 June, 2013. Westin Grand, Berlin, Germany.

Shah, M. H. (2014a). The role of human capital in the host economy on inward FDI in developing countries. West East Institute, European Academic Conference Budapest, WEI 2014, $22-25$ June, 2014. Mercure Budapest Korona, Hungary. Organized by West East Institute, 19382 West Chester, PA, USA.

Shah, M. H. (2014b). The significance of infrastructure for FDI inflow in developing countries. Journal of Life Economics, 2, 1-16.

Shah, M. H., \& Qayyum, S. (2015). Impact of double taxation treaties on inward FDI in Latin American and Caribbean developing countries. Business $\mathcal{E}$ Economic Review. 7(1), 1-18.

Shah, M. H. (2015). Impact of trade liberalization on FDI inflows in emerging countries. International Social Sciences and Education Research Conference ICBTS2015, 9-13 June, 2015 at Harvard University, Boston, Massachusetts, USA.

Shah, M. H., \& Faiz, M. (2015). Terrorism and foreign direct investment: An empirical analysis of SAARC countries. City University Research Journal. 5(2), 219-233.

Shah, M. H., \& Samdani, S. (2015). Impact of trade liberalization on FDI inflows to D-8 countries. Global Management Journal for Academic $\mathcal{E}$ Corporate Studies, 5(1), 30-37.

Shah, M. H., \& Afridi, A. G. (2015). Significance of good governance for FDI inflows in SAARC countries. Business $\mathcal{E}$ Economic Review. 7(2), 31-52.

Sharifi-Renani, H., \& Mirfatah, M. (2012). The impact of exchange rate volatility on foreign direct investment in Iran. Procedia Economics and Finance. 1, 365-373.

Tiwari, A. K., \& Mutascu, M. (2011). Economic growth and FDI in Asia: A panel-data approach. Economic Analysis and Policy, 41(2), 173-187.

Tsen, W. H. (2005). The determinants of foreign direct investment in the manufacturing industry of Malaysia. Journal of Economic Cooperation, 26(2), 91-110.

Yasmin, B., Hussain, A., \& Chaudhary, M. A. (2003). Analysis of factors affecting foreign direct investment in developing countries. Pakistan Economic and Social Review, 41(1/2), 59-75. 
